\title{
近畿地区健診懇話会・資料提供 早期発見の值段
}

\author{
世話人・清島啓治郎*
}

\section{早期発見の值段 ?}

欧米には“Price of early detection”という考え方が あると聞く。Early detection（早期発見）は，日本人 には「完治の切り札」「病死回避の秘策」として尊いが, 議論はその尊さまでで,「その值段は？」という発想が 続くことはない。もし早期発見の尊さを欧米風にPrice として見たらどうなるか。

値段とは，物を入手するのに払う金額，価值つまり有 難味を金額になおしたものであろうが, 值段には, 物造 りに要する費用（生産原価）次第の数字, という面もあ る。

\section{人間ドックと総合健診}

総合健診の人間ドックとの差の筆頭は現代向きのス ピードであろう。人間ドック（日本病院会集計の「一泊 人間ドック」) が全国 614 施設, 計 2,314 ベッドで年間 33 万件の健康審査を行なうのに比して, 総合健診（同 集計の「一日人間ドック」）は全国 269 施設で，年間 161 万件（一泊人間ドックの 5 倍弱）の健康審査を行 なっている。平成 3 年と 14 年を比べてバブル崩壊前後 の差を見ると, 人間ドックが 33 万 5 千件から 33 万件へ と 7\%減ったのに比べ, 総合健診は 111 万件から 161 万 件へと 45\%増え, 新幹線に代表される時代のスピード 願望は, 不況の中も変らぬと見て取ることができる（表 1)。

\section{早期発見の生産原価}

早期発見が命を拾った本人にとってめでたいのは無論 だが，医療費面ではどうか。早期発見は医療費を安くす ると言えるだろうか。仮に早期発見が医療費を減らすと しても, その減り幅は, 早期発見のため, つまり健診充 実のためのコスト増, すなわち検診料増に見合うか。

これは健康保険組合の健診事業にとり看過できぬ問題 である。ずさんな健診に早期発見は期待できない。

早期発見が可能な健診の要件（表 2）は，そのまま日 本総合健診医学会の優良施設認定基準に合致するが, ど

* PL 大阪健康管理センター
の要件も人件費と設備費を高くし, 健診の生産原価を上 げる関係にあるのが分かる。

生産原価を増やしてでも早期発見をねらうべきか。早 期発見の有難味はどのくらいと見積もるべきか。

我々は早期発見の経済効果を見るため, 死因第 1 位の 癌である肺癌を取り上げ, 早期発見例 4 例と進行発見例 3 例で，かかった医療費を比較してみた。

\section{肺癌治療費の比較（早期癌と進行癌）}

在近畿の某胸部外科専門医療機関における, 代表的肺 癌 7 例（進行 3, 早期 4）の手術時医療費を表 3 に示す。 治療費は, 早期発見例では発見に続く手術時の入院だけ で完結するが, 進行癌症例では退院後に長い通院治療 と,さらに何度かの再入院の費用が加わる。

早期癌症例は, 手術時入院が平均 20 日間, 入院治療 費は平均 126 万円, 術後通院は 1 年間約 10 日で終わる。

進行癌症例は手術時入院が平均 37 日間, 入院治療費 が平均 216 万円であり,これだけ見ると早期癌の 1.7 倍

表 1

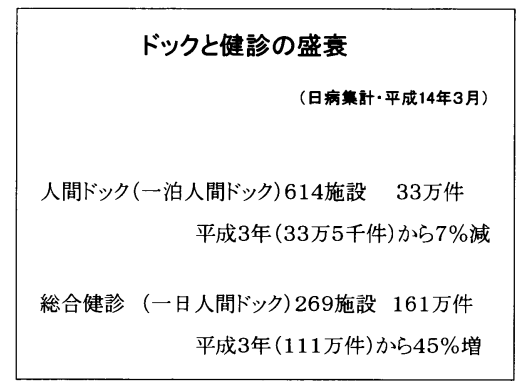

表 2

早期発見が可能な健診の要件

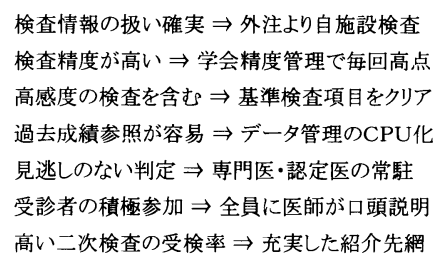

検查情報の扱い確実 $\Rightarrow$ 外注より自施設検査

検査精度が高い $\Rightarrow$ 学会精度管理で毎回高点

高感度の検查を含む $\Rightarrow$ 基準検査項目をクリア

管理のCPU化

受診者の積極参加 $\Rightarrow$ 全員に医師が口頭説明

高い二次検查の受検率 $\Rightarrow$ 充実した紹介先網 
表 3

\begin{tabular}{|c|c|c|c|}
\hline \multicolumn{4}{|c|}{ 手術入院費の比較 一進行肺癌と早期肺癌一 } \\
\hline 病 期 & 術 式 & 入院日数 & 総点数 $*$ \\
\hline 進行肺癌 1 & 気管支形成術 & 34 & 199,763 \\
\hline 進行肺癌 2 & 胸膜及肺全摘 & 47 & 272,820 \\
\hline 進行肺癌 3 & 胸壁合併切除 & 31 & 175,750 \\
\hline 進行肺癌平均 & & 37 & 216,111 \\
\hline 早期肺癌 1 & 肺部分切除 & 23 & 159,675 \\
\hline 早期肺癌 2 & 肺部分切除 & 17 & 129,680 \\
\hline 早期肺癌 3 & 肺部分切除 & 25 & 103,984 \\
\hline 早期肺癌 4 & 肺部分切除 & 16 & 111,342 \\
\hline 早期肺癌平均 & & 20 & 126,170 \\
\hline
\end{tabular}

表 4

進行肺癌: 術後の再入院と通院の医療費

\begin{tabular}{|c|c|c|c|c|c|c|}
\hline 手街入院一(1) & 手椾入院一(2) & 手输入院一(3) & 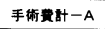 & & & \\
\hline 13. 5. 31 & 13. 6.29 & 13. 7.31 & & & & \\
\hline 174,428 & 89,301 & 9,091 & 272,820 & & & \\
\hline 愫後外来 & 徒後外来 & 征後外来 & 術後外来 & 街後外来 & 㫱後外来 & 唡後外来 \\
\hline 13. 10.2 & 13. 10.6 & 13. 10.9 & 13. 10.10 & 13. 10.12 & 13. 10. 16 & 13. 10. 31 \\
\hline 1,619 & 432 & 448 & 787 & 136 & 2,165 & 292 \\
\hline 街後外来 & 䚘後外来 & 䚘後外来 & 赫後外来 & 赫後外来 & 踰後外来 & 外来费斯 $-\mathrm{B}$ \\
\hline 13. 10.24 & 13. 11.1 & 13. 11.5 & 13. 11.6 & 13. 11.9 & 13. 11.13 & \\
\hline 323 & 136 & 136 & 681 & 1,364 & 1,454 & 9,973 \\
\hline 再入院-(1) & 再入院一(2) & 再入院一(3) & 再入院-C & & 街後賈總計 & 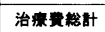 \\
\hline 13. 12.31 & 13. 12. 31 & 14. 1.1 & & & $B+C$ & $A+B+C$ \\
\hline 27,409 & 120,564 & 1,588 & 149,561 & & 159,534 & 432,354 \\
\hline
\end{tabular}

止まりであるが, 術後に長い通院と再発に伴う再入院を 要し, 総額では早期癌症例の 3 倍にも達する。

\section{進行肺癌例の死亡までの全医療費}

手術を受けいったん退院した後, 通院, 再入院等を最 終（死亡）まで追跡し得た進行肺癌例 B（術式：胸膜お よび肺全剔）の退院後医療費を 1 例として表 4 に示す。

外来通院 10 万円, 3 回の再入院費用計 150 万円で合 計 160 万円。手術入院時の医療費 273 万円に加えると 433 万円で，早期発見例の平均医療費 126 万円の 3.4 倍, 差額は 307 万円に達した。早期発見の経済効果を示 す一つの例といえよう。

\section{早期発見の救命・延命効果}

早期発見の延命効果は肺癌の場合きわめて顕著で， I $\mathrm{A}$ 期（早期）非小細胞癌では図10ように高いが, pN 2-3（進行）非小細胞癌では図 2 のように低い。

注目すべきは, 同じ I A 期の癌腫でも, 直径 15 ミリ 以下と以上とでは術後生存率に大差がある点で, 小さい うちに見つけることの重要さを示している。

\section{肺病変示現率の比較一単純写真と CT-}

この直径 15 ミリというサイズは, 日本人に多い腺癌 の場合, 平面写真では淡い影しか作らず発見が難しいの に，CTではきわめて容易に見つかり，検査法の差が診

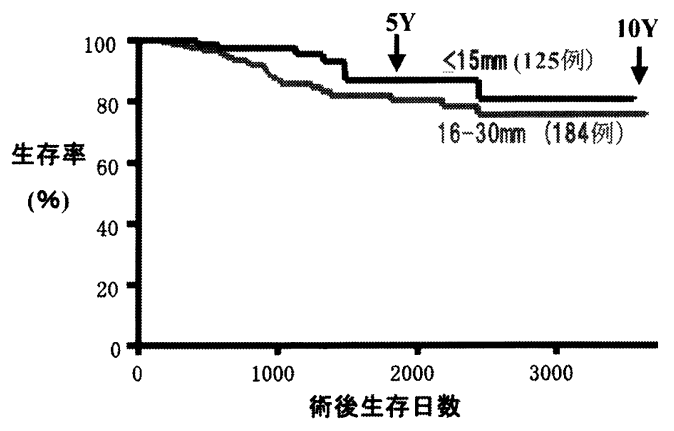

$I A$ 期非小細胞肺絽 大閳府立成人房センター

図 1

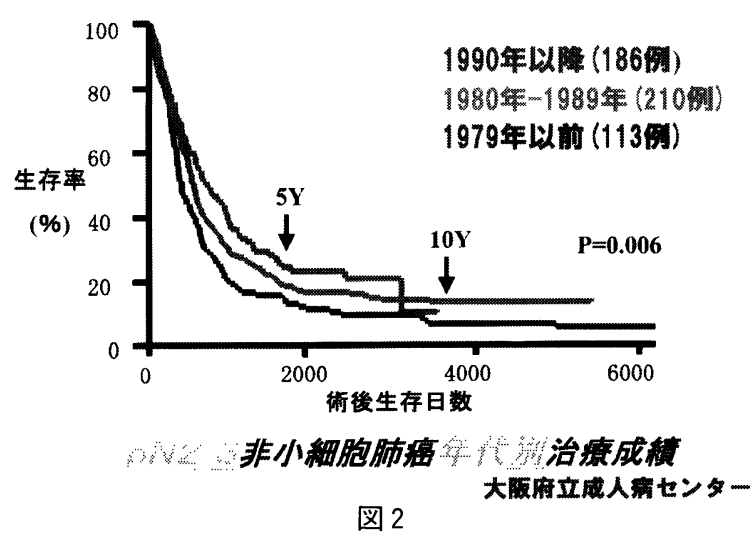

腫瘤径別に見た腫㾇指摘能の比較

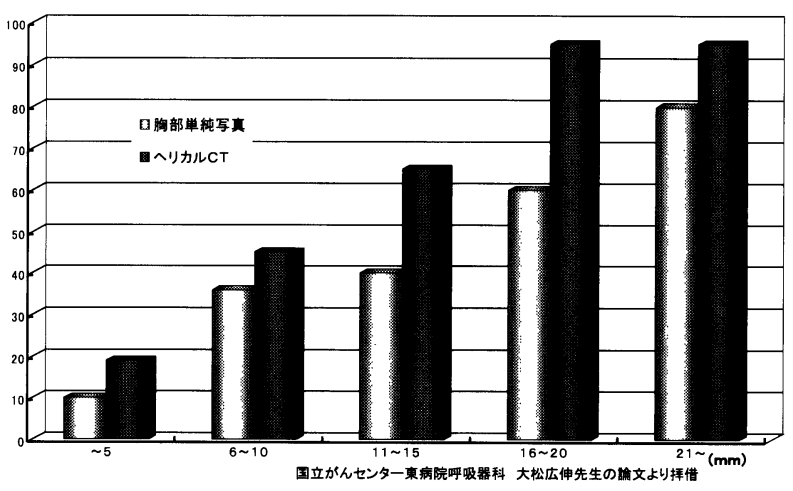

図 3

断に響くサイズといえる。

国立がんセンターの大松氏は，単純写真と CT の病変 示現力の違いを図 3 のように示し，15～20ミリの腫瘤 で最も両者の差がつくとしている。

1 ミリや 2 ミリの癌はCT でも見えない。 30 ミリを超 えれば単純写真でも簡単に見える。両者の間の 15 ミリ 前後は, CT では見え単純写真では見えない, つまり才 カルト陰影であるが，この辺りの差が生存率を左右する となると，健診が気軽に CT につなぐ体制を備えている か否かは, その健診システムの救命力という関係になっ てくる。 


\section{発見率の検査依存度が高い分野}

名人芸か, 先進の検査か。単純写真の淡い影を見つけ る名人芸も尊いが，肺野の小腺癌のように単純写真では 極度に淡い，あるいは全く写ら妃ルト癌（図 4）ま で描出する, 高速らせんCT の健診への導入も, そろそ ろ考慮してよいのではなかろうか。

「東京から肺癌をなくす会」の成績に見る高速らせん CT の効用

「東京から肺癌をなくす会」は，高速らせん CT 導 入した 1975 年の前後で肺癌発見の成果を比較し, 発見 率が対 10 万人換算で 163 人から 391 人へ 2.4 倍に, 病 期別では I 期発見が $54 \%$ から $83 \%$ へ 1.5 倍に，また 5 年生存率は $49 \%$ から $83 \%$ へ 1.7 倍になったという（図 $5)$ 。

\section{PSA 導入で急増した前立腺癌発見}

日本人男子の癌の中で，いま死亡数の増加率が最も高 いのは前立腺癌とされる。

PSA 検査の導入で PL 大阪健康管理センターの前立 腺癌発見が急増したようすを図 6 と図 7 に示す。

前立腺癌発見力は(1)指診, (2)経直腸超音波, (3) PSA の 3 者では PSA が最強で, PSAの前立癌マーカーと しての信頼性は確立されている。

この傾向は，ドックの歷史が長い聖路加国際病院でも 同様で，発見率はPSA 導入により 1 週間ドックで 13 倍，1日ドックで 4.6 倍に増えたという。

\section{前立腺癌医療費の病期別比較}

前立腺癌では, 進行癌と早期癌の治療費の差が, 肺癌 よりさらに大きい。

表 5 の左に示す早期全剔手術例は, 31 日間入院し,
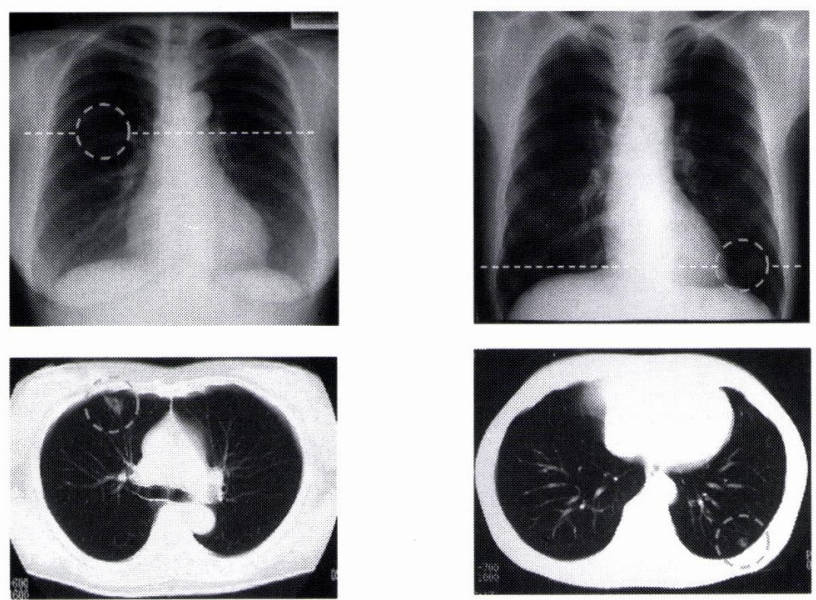

図 4

\begin{tabular}{|c|c|c|}
\hline \multicolumn{3}{|c|}{ 「東京から肺がんをなくす会」肺がん発見状況 } \\
\hline \multicolumn{3}{|c|}{ 一高速らせんCT導入前·後の比較一 } \\
\hline & 導入前 & 導入後 \\
\hline & $1975 / 9 \sim 93 / 8$ & $1993 / 9 \sim 2001 / 8$ \\
\hline 総受診者 & 26,388 人 & 13,796 人 \\
\hline 発見肺がん例 & 43 人 & 54 人 \\
\hline 発見数 $\div$ 受診者数 & $0,16 \%$ & $0,39 \%$ \\
\hline 発見数 (対 10 万換算) & 163人 & 391 人 \\
\hline CTなしでも発見可能 & & $123 人$ \\
\hline CTなしでは発見困難 & & 268人 \\
\hline I A期 & $41.9 \%$ & $83.3 \%$ \\
\hline I B期 & $11.6 \%$ & $1.9 \%$ \\
\hline II A 期 & $7.0 \%$ & $1.9 \%$ \\
\hline II B期 & $7.0 \%$ & $0 \%$ \\
\hline IIIA期 & $18.6 \%$ & $7.4 \%$ \\
\hline III B期 & $2.3 \%$ & $3.7 \%$ \\
\hline IV期 & $11.6 \%$ & $1.9 \%$ \\
\hline
\end{tabular}

図 5

前立腺癌発見数の年次推移

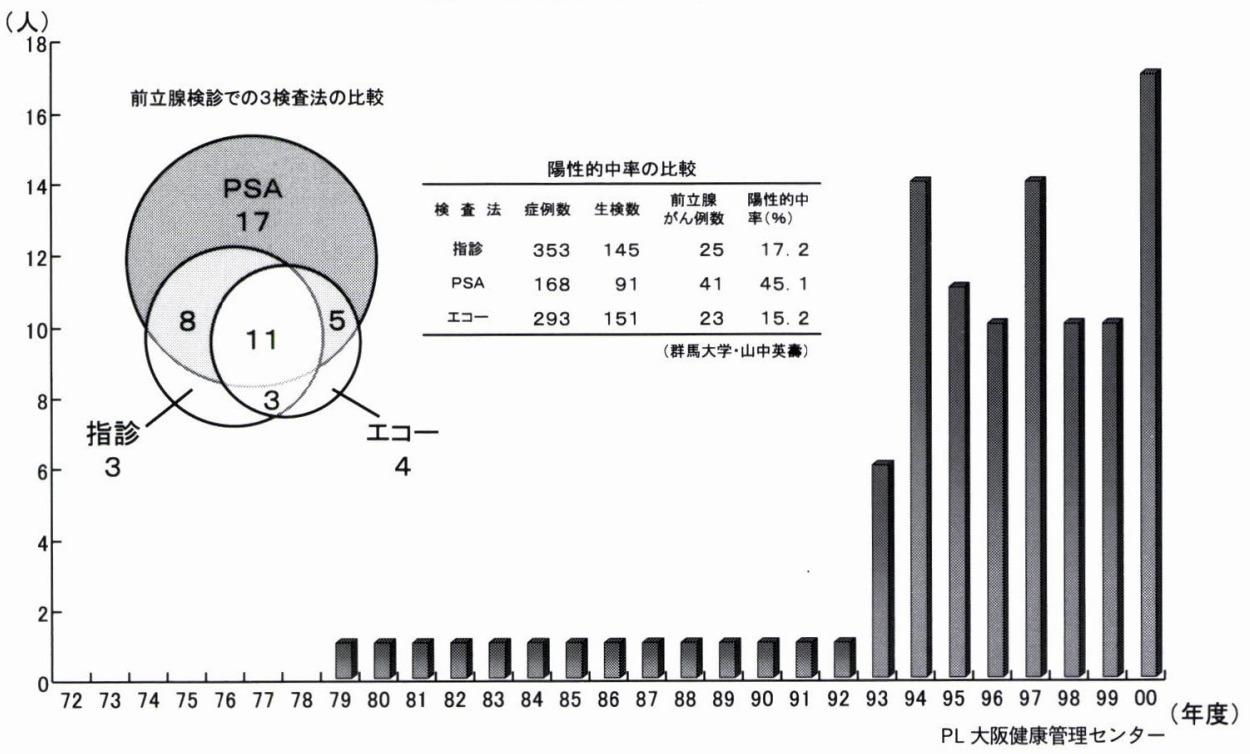

図 6 
術後 1 年間経過観察で 3 回通院して完治した。

治療費は入院治療が 105 万円, 通院観察が 3 万円, 計 108 万円であった。

表 5 の右に示す進行前立腺癌症例は手術不能で通院注 射療法を受け，月約 11 万円， 1 年で 127 万円の治療費 が，転移による死亡まで 4 年間つづき，合計 509 万円で あった。早期癌治療費の 4.7 倍かかったことになる。

\section{便潜血定量検査 3 日法で急増した大腸癌発見}

便潜血による大腸癌スクリーニングでも, 免疫学的定 量法で 3 回調べ, 判定法に工夫をこらすことで発見率が 画期的に高まることを我々は経験した（図 8)。

1 日法, 2 日法に比べ検査費用（生産原価）は高くは なるが，増額は微々たるもので，大腸癌早期発見による 救命で酬いられて余りあり, Cost performance はきわ めて高いと言ってよい。

\section{まとめ}

1. 早期発見が治療費の削減につながるか否か見るた め, 肺癌と前立腺癌とで, 早期発見症例と進行癌症例と

\begin{tabular}{|c|c|c|}
\hline & 聖路加国際病院ドック前立腺癌発見率 & 見率 \\
\hline & 1週間ドック & 1日ドック \\
\hline $\begin{array}{l}\text { PSA導入前 } \\
\text { (1967 1994年) }\end{array}$ & $\begin{array}{l}\text { O. } 28 \% \\
(19 / 6,856)\end{array}$ & $\begin{array}{c}0.03 \% \\
(7 / 22,880)\end{array}$ \\
\hline & $\downarrow$ & $\downarrow$ \\
\hline & $\downarrow$ & $\downarrow$ \\
\hline $\begin{array}{l}\text { OPSA筫入後 } \\
\text { (1995 1998年) }\end{array}$ & $\begin{array}{l}\text { 3. } 70 \% \\
(12 / 328)\end{array}$ & $\begin{array}{c}\text { O. } 14 \% \\
(17 / 11,776)\end{array}$ \\
\hline
\end{tabular}

図 7
の総治療費を比べた。肺癌は進行癌では 375 万円，早期 癌では 126 万円（進行癌の 30\%), 前立腺癌は進行癌で は 509 万円，早期癌では 108 万円（進行癌の 21\%）で あった。早期発見の治療費削減効果はー70\%〜-79\%と 顕著であった。

2. 早期発見が可能な健診の要件は，本学会の優良健 診施設認定基準が求める内容に一致しており，いずれも 健診の生産原価を高める関係にあるが，これは早期発 見・早期治療がもたらす大幅な治療費の節減によって酬

表 5

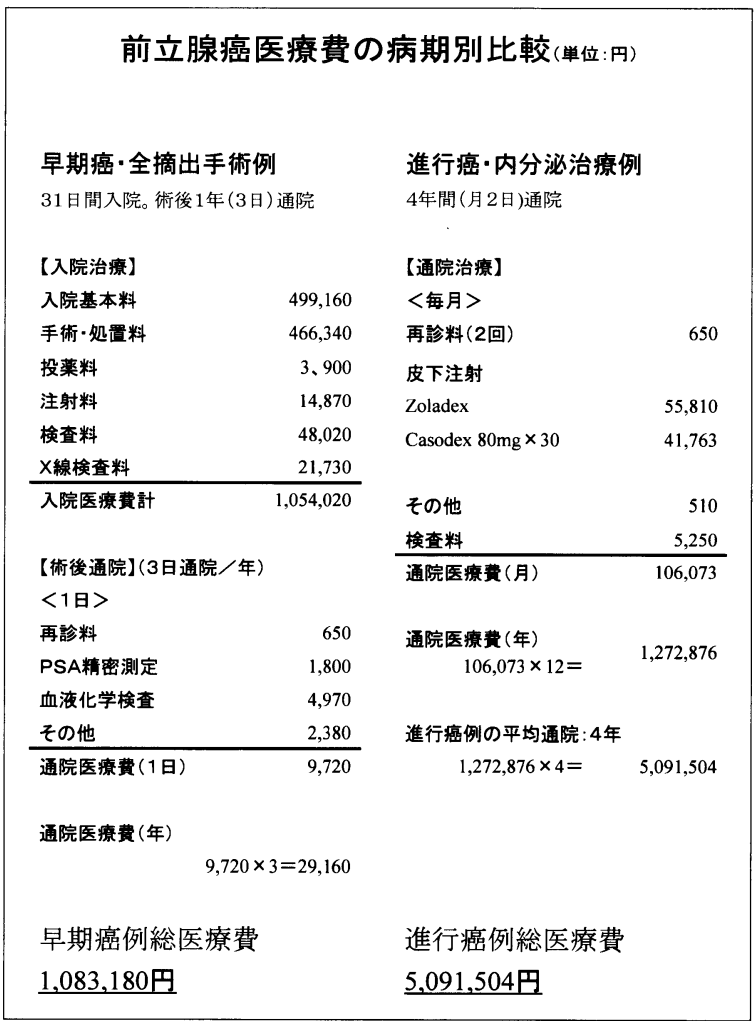

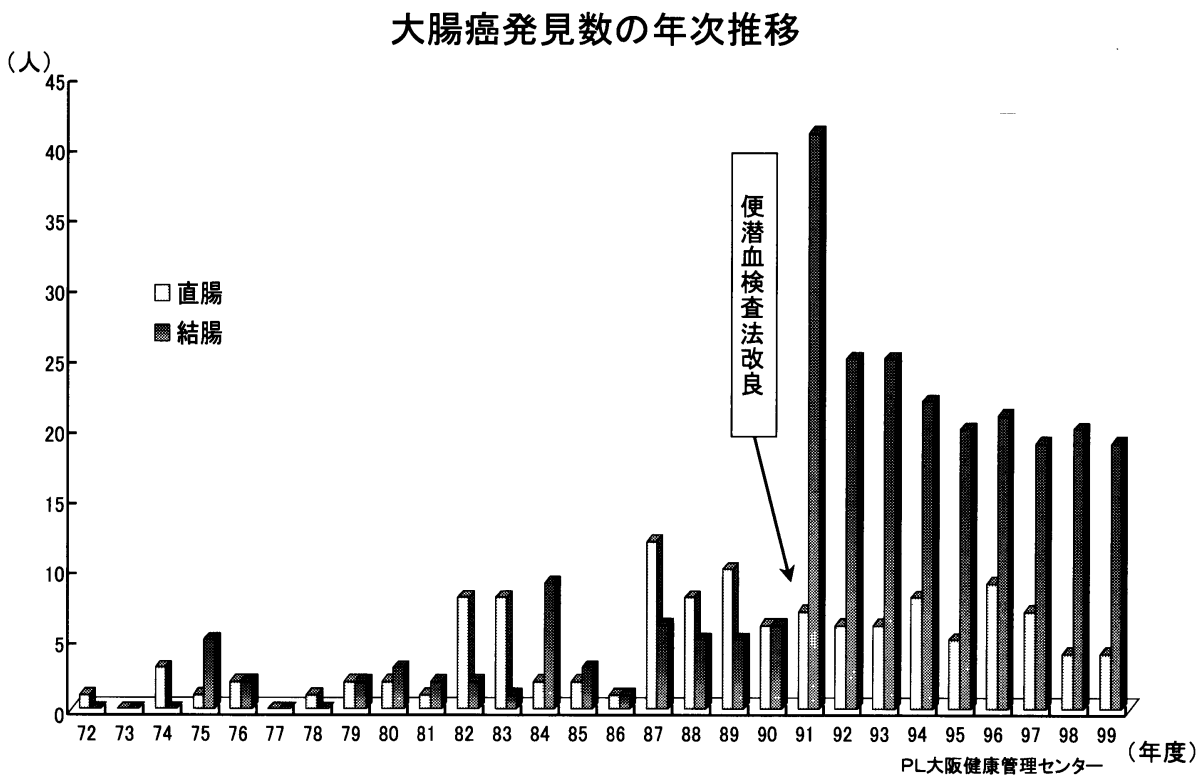

図 8 
いられ，「優良」維持のための経費は Cost performance の高いものと言える。

3. 癌をはじめ致死的疾患の多くは, 発生率と年齢・ 既往歷・家族歷の間に密接な関係があり, 個々の受診者 に必要な検査, 不要な検査を見きわめ, 健診の検査メ ニューを合理化する努力が，組合・健診側合同で重ねら れねばならぬ。
4. 健診側は組合の健診事業事情を理解し，実益の上 がる健診を極限まで追及せねばならない。

早期発見力が高く，かつ必要最小限に項目を絞った良 い健診を求め, 組合・健診側両者間で話し合う場を頻繁 に持つ必要がある。その過程で, 妥当な健診料も自然に 導き出されてくるのではなかろうか。

(2002 年 11 月 21 日近畿健診愁話会での口演記録) 